\title{
BLOOD 5-HYDROXYTRYPTAMINE LEVELS IN THE NEWBORN
}

\author{
BY \\ MEENA HAZRA*, SYLVIA BENSON, and M. SANDLER $\dagger$ \\ From the Bernhard Baron Memorial Research Laboratories and Institute of Obstetrics and \\ Gynaecology, Queen Charlotte's Maternity Hospital, London
}

(RECEIVED FOR PUBLICATION DECEMBER 18, 1964)

During the course of a long-term investigation, still in progress, designed to shed light on the observation of Pare, Sandler, and Stacey (1960) that certain children with mental handicap have high blood 5-hydroxytryptamine (5HT) concentrations, some data on levels in normal newborn infants were obtained which seem to be worthy of record.

\section{Method}

Whole-blood 5HT levels were measured by the method of Contractor (1964) with the following modifications. (a) Capillary blood obtained from the heel with minimal squeezing was used instead of venous blood. It had previously been established in four normal adults that SHT levels in capillary and venous blood drawn simultaneously were in close agreement.

(b) The procedure was scaled down to allow the use of $1 \mathrm{ml}$. blood instead of $2 \mathrm{ml}$. and carboxymethylcellulose columns were reduced in height from 10 to $5 \mathrm{~cm}$. These changes inevitably reduced the sensitivity of the procedure and increased the error of the method from $\pm 5 \%$ to \pm $36 \%$, but as the observed changes in blood levels in each age-group were greater than this margin of error, they were considered to be significant.

Platelets were counted by the method of Dacie and Lewis (1963).

\section{Results}

Samples of capillary blood were taken from normal full-term infants at 1 day and 1 week of life

* Present address: Department of Paediatrics, Civil Hospital, Ahmedabad, India.

† Requests for reprints should be sent to M. Sandler. while in Queen Charlotte's Hospital; follow-up samples were subsequently obtained at 4-6 weeks, 12 weeks, and 24 weeks while at home, though some infants were not accessible for the later samples. Results are shown in the Table.

Values were low at birth but then rose to reach a peak at 4-6 weeks, there being a highly significant difference between mean values at these periods despite the wide scatter of individual concentrations. There was a significant drop at 12 weeks, after which levels remained constant.

The mean platelet count on day 1 was $166,000 \pm$ 25,000 (S.D.) per c.mm. and did not change significantly throughout the investigation.

\section{Discussion}

Although it has previously been established that circulating 5HT levels are low at birth, no detailed study of changes in concentration during the first six months of life has hitherto been published. Taking the difference of method into account, values determined by Mitchell and Cass (1959) in umbilical venous blood $(12 \pm 12 \mathrm{~m} \mu \mathrm{g} . / \mathrm{ml}$.) are not dissimilar from those described here. It is not possible to compare our findings with those of Grasso, Bianchi, Crosti, and Ermacora (1961), however, for though they found significantly low levels in the newborn period, they expressed their results in terms of concentration per $10^{9}$ platelets.

The cause of these low values remains speculative.

TABLE

WHOLE BLOOD 5-HYDROXYTRYPTAMINE LEVELS (m $\mu \mathrm{g} . / \mathrm{ml}$.) FROM BIRTH TO 24 WEEKS OF AGE

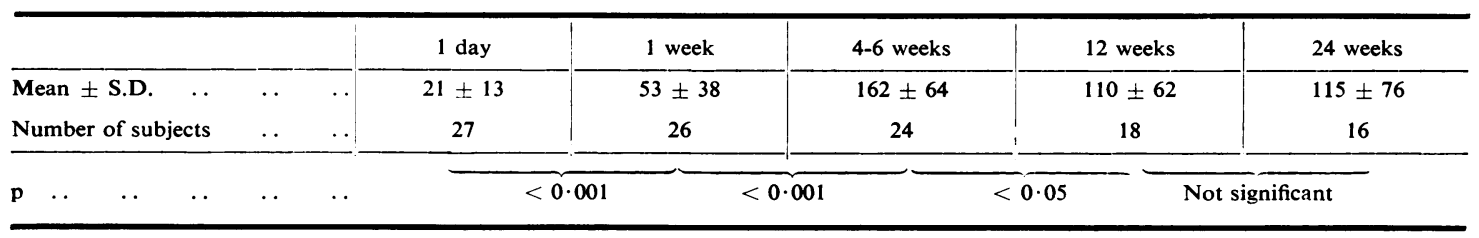


It is generally agreed that circulating $5 \mathrm{HT}$ is bound almost wholly to blood platelets. The present data, however, show platelet counts to lie within the normal adult range (Dacie and Lewis, 1963). There does not appear to be any defective uptake of 5HT by platelets deriving from cord blood (Stacey, 1965), despite a limited experiment implying the contrary by Mitchell and Cass (1959). Enhanced breakdown of 5HT, though theoretically possible, is unlikely, for monoamine oxidase, the enzyme largely responsible for its inactivation, is decreased during the newborn period both in the human (Epps, 1945) and in the rat (Shimizu and Morikawa, 1959; Nachmias, 1960; Karki, Kuntzman, and Brodie, 1962). Endogenous release of 5HT from viable platelets has never been demonstrated under physiological conditions, though some exchange of radio-isotopically labelled amine has been noted in patients with the carcinoid syndrome (Zucker, Hellman, and Zumoff, 1964), and alkaline extracts of various tissues can provoke such release in vitro (Toh, 1956; Giarman, Potter, and Day, 1960).

In certain experimental animals, brain 5HT levels are low at birth (Kato, 1960; Nachmias, 1960; Karki et al., 1962; Smith, Stacey, and Young, 1962; Hsia, Nishimura, and Brenchley, 1963), though there is some species variation (Pepeu and Giarman, 1962). If this finding can be extrapolated to man, there exists the likelihood of defective synthesis of 5HT in early life. In common with some other enzyme systems (Driscoll and Hsia, 1958), 5-hydroxytryptophan decarboxylase, which elaborates 5HT from its precursor amino acid, has a decreased activity during the newborn period in several species, though this reduction varies very much with the tissue (Huang, Tannenbaum, and Hsia, 1960; Smith et al., 1962; Karki et al., 1962; Hsia et al., 1963). Bennett and Giarman (1964), however, indicate that defective tryptophan 5-hydroxylation is more likely to be responsible for low 5HT levels encountered in the newborn rat.

Mitchell and Cass (1959) formed the impression that an increase in blood 5HT content occurs rather abruptly at 16-20 weeks of age, but as their contention was based on 8 single estimations in different children, it is not possible to attach much significance to their findings. The considerably larger series reported here shows that a rise to adult levels (Contractor, 1964) occurs gradually and is maximal by the 4-6th week of life. As discussed above, its cause is presumably conrected with the maturation of enzyme systems at the site of synthesis and is independent of platelet number. Stacey and Young (1964) have shown in the newborn guinea-pig that platelet 5HT level rises in parallel to, and thus probably derives from, intestinal 5HT content. It does not seem too unlikely that a similar connexion may exist in the human infant.

Though it was not practicable to measure 24-hour urinary output of the major metabolite of 5HT, 5-hydroxyindoleacetic acid, in our series, because of difficulties in collection of specimens, the data of other workers (Serra, 1958; Rappallini and Murtagh, 1962) suggest that, expressed per kilogram body weight, there is a low rate of 5HT synthesis in the newborn period, which rises to approximately adult levels after 1 month (Serra, 1958). While this finding mirrors our own observations, their work might usefully be repeated using more precise analytical methods.

\section{Summary}

Whole blood 5-hydroxytryptamine (5HT) levels, determined in a series of normal full-term infants, were low at birth $(21 \pm 13 \mathrm{~m} \mu \mathrm{g}$. $/ \mathrm{ml}$.) but rose to adult concentrations $(162 \pm 64 \mathrm{~m} \mu \mathrm{g} . / \mathrm{ml}$.) by $4-6$ weeks of life, though blood platelet counts remained unchanged. These findings are likely to be connected with the maturation of enzymes responsible for 5-hydroxytryptamine synthesis.

This work was supported by a generous grant from the National Society for Mentally Handicapped Children who defrayed the salaries of M.H. and S.B.

We are grateful to Dr. A. White Franklin and Dr. A. P. Norman for allowing us to examine their patients, to Miss Glenda Hale for carrying out platelet counts, and to the mothers of the infants tested whose willing co-operation made the investigation possible.

\section{REFERENCES}

Bennett, D. S., and Giarman, N. J. (1964). Schedule of appearance of serotonin (5-HT) and associated enzymes in developing rat brain. Pharmacologist, 6, 171 .

Contractor, S. F. (1964). The estimation of 5-hydroxytryptamine in human blood. Biochem. Pharmacol., 13, 1351.

Dacie, J. V., and Lewis, S. M. (1963). Practical Haematology, 3rd ed., p. 61. Churchill, London.

Driscoll, S. G., and Hsia, D. Y.-Y. (1958). The development of enzyme systems during early infancy. Pediatrics, 22, 785.

Epps, H. M. R. (1945). The development of amine oxidase activity by human tissues after birth. Biochem. J., 39, 37.

Giarman, N. J., Potter, L. T., and Day, M. (1960). Release of 5-hydroxytryptamine and histamine from neoplastic mast cells by alkaline tissue extracts. Experientia (Basel), 16, 492.

Grasso, E., Bianchi, P., Crosti, P. F., and Ermacora, E. (1961). The pathogenesis of haemorrhages in newborn babies. Experimental observations of the platelet serotonin. Panminerva med., $3,49$.

Hsia, D. Y.-Y., Nishimura, K., and Brenchley, Y. (1963). Mechanisms for the decrease of brain serotonin. Nature (Lond.), 200, 578.

Huang, I., Tannenbaum, S., and Hsia, D. Y.-Y. (1960). Development of 5-hydroxytryptophan decarboxylase activity in rat kidney. ibid., 186, 717.

Karki, N., Kuntzman, R., and Brodie, B. B. (1962). Storage synthesis, and metabolism of monoamines in the developing brain. J. Neuro:hem., 9, 53. 
Kato, R. (1960). Serotonin content of rat brain in relation to sex and age. ibid., 5, 202.

Mitchell, R. G., and Cass, R. (1959). Histamine and 5-hydroxytryptamine in the blood of infants and children. J. clin. Invest. 38, 595 .

Nachmias, V. T. (1960). Amine oxidase and 5-hydroxytryptamine in developing rat brain. J. Neurochem., 6, 99.

Pare, C. M. B., Sandler, M., and Stacey, R. S. (1960). 5-Hydroxyindoles in mental deficiency. J. Neurol. Neurosurg. Psychiat., 23, 341.

Pepeu, G., and Giarman, N. J. (1962). Serotonin in the developing mammal. J. gen. Physiol., 45, 575.

Rappallini, C., and Murtagh, J. J. (1962). La serotonina y el acido 5-hidroxindolacetico en el recien nacido. Sem. méd. (B. Aires), 121, 1239

Serra, U. (1958). L'eliminazione urinaria dell'acido 5-idroxindol acetico in bambini normali. Fol. endocr. (Roma), 11, 410.

Shimizu, N., and Morikawa, N. (1959). Histochemical study of monoamine oxidase in the developing rat brain. Nature (Lond.), 184,650 .
Smith, S. E., Stacey, R. S., and Young, I. M. (1962). 5-hydroxytryptamine and 5-hydroxytryptophan decarboxylase activity in the developing nervous system of rats and guinea-pigs. In Proc. 1st int. pharmacol. Meeting, vol. 8, Pharmacological Analysis of Central Nervous System, p. 101. Pergamon Press, Oxford.

Stacey, R. S. (1965). Clinical aspects of cerebral and extracerebral 5-hydroxytryptamine. In 5-Hydroxytryptamine and Related Indolealkylamines. (Heffter's Handbuch der experimentellen Pharmakologie, Vol. 19, ed. V. Erspamer), p. 744. Springer, Berlin.

- , and Young, I. M. (1964). Concentration of 5-hydroxytryptamine in the small intestine and platelets of the developing guinea pig. Biochem. Pharmacol., 13, 129.

Toh, C. C. (1956). Release of 5-hydroxytryptamine (serotonin) and histamine from platelets by tissue extracts. J. Physiol. (Lond.) $133,402$.

Zucker, M. B., Hellman, L., and Zumoff, B. (1964). Rapid disappearance of $\mathrm{C}^{14}$-labeled serotonin from platelets in patients with carcinoid syndrome. J. Lab. clin. Med.. 63, 137. 